\title{
LOYALTY AND DISTINCTIVENESS: \\ A New ApProach to The Crown's Fiduciary Duty Toward Aboriginal Peoples
}

\author{
Michael Coyle
}

As a tool to protect the distinctive elements of Aboriginal cultures, the Supreme Court's current approach to s. 35 of the Charter has significant limitations. The judgments of the majority and of the minority in R. $v$. Mitchell illustrate these limitations, but also hint at the possibility of a fuller, more coherent protection of Aboriginal rights. This article argues that the Court should recognize that the Crown has a fiduciary duty to negotiate in good faith a "protected space" for those Aboriginal institutions necessary for cultural survival.
En tant qu'outil de protection dëléments distincts des cultures autochtones, la démarche actuelle de la Cour suprême à l'ëgard de l'article 35 de la Charte présente de sérieuses limitations. Les jugements de la majorite et de la minorite dans l'affaire R. $c$. Mitchell illustrent ces limitations tout en faisant référence $\dot{a}$ une protection plus grande et plus cohérente des droits des autochtones. Cet article fait valoir le fait que la Cour devrait reconnaitre que la Couronne a le devoir fiduciaire de négocier en toute bonne foi un espace protégé pour les institutions autochtones qui sont nécessaires à la survie de la culture.

\section{TABLE OF CONTENTS}

I. INTRODUCTION $\ldots \ldots \ldots \ldots \ldots \ldots \ldots \ldots \ldots \ldots \ldots \ldots \ldots$

II. THE LiMITATIONS OF THE CURRENT

APPROACH TO SECTION $35 \ldots \ldots \ldots \ldots \ldots \ldots \ldots$

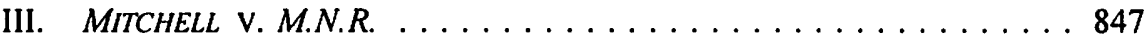

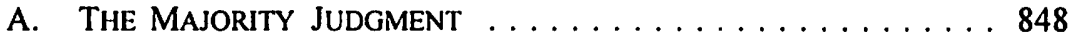

B. THE MINORITY JUDGMENT $\ldots \ldots \ldots \ldots \ldots \ldots \ldots 1$

IV. A NEW CONCEPTION OF THE FIDUCIARY RELATIONSHIP

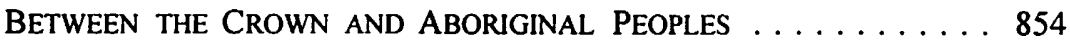

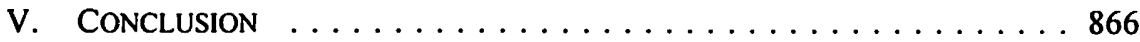

[Aboriginal rights] find their source in an earlier age, but they have not been frozen in time. They are, as has been said, rights not relics. They are projected into modern Canada where they are exercised as group rights in the 21 st century by modern Canadians who wish to preserve and protect their aboriginal identity.

- Justice Binnie in Mitchell v. M.N.R.'

\section{INTRODUCTION}

The Supreme Court of Canada has had to tread a delicate course recently in defining the constitutional rights of Aboriginal peoples. Crown prosecutions and Aboriginal

Assistant Professor, Faculty of Law, University of Western Ontario. From 1989 to 2000, Professor Coyle served as Senior Counsel to the Indian Commission of Ontario. The author acknowledges with gratitude the assistance of Professor Alan Grant, emeritus of Osgoode Hall Law School at York University, and of my colleagues Professors Joanna Harrington and Stephen Pitel, all of whom were kind enough to comment on earlier drafts of this article.

1 Mitchell v. M.N.R., [2001] I S.C.R. 911 at para. 132 [hereinafter Mitchell]. 
claims that have found their way to the court have required it to consider whether protected Aboriginal rights include commercial fishing, ${ }^{2}$ high-stakes gambling, ${ }^{3}$ a continuing interest in vast tracts of land ${ }^{4}$ and, most recently, the right to bring goods over the Canadian border exempt from customs duties. ${ }^{5}$ Throughout, the Court has used as its touchstone a purposive approach to interpreting s. 35 of the Constitution Act, $1982 .^{6}$ The purpose of $\mathrm{s} .35$, according to the court, ${ }^{7}$ is to reconcile the historical reality of Aboriginal societies' first occupation of this land with the current fact of Crown sovereignty under the Constitution.

Unsurprisingly, determining how to achieve that equitable reconciliation has proved no more simple a task for the courts than it has been for political leaders and Canadian society at large. The Supreme Court of Canada in particular has tried to combine broad expressions of guidance on the interpretation of s. 35 with a concrete, fact-focused approach to each case that has its roots in the traditions of the common law courts. ${ }^{8}$ At times this approach has meant that the court has taken a leadership role in defining the extent of Aboriginal rights in Canada. That role has included offering guidance for triers of fact in future claims and, where appropriate, encouragement to the Crown and Aboriginal leaders to find a negotiated resolution of their concerns." The legal framework for analyzing s. 35 claims continues to be clarified and, naturally, to evolve. Nonetheless, that framework, as it currently stands, risks permitting the destruction of the distinct Aboriginal cultures that $\mathrm{s} .35$ is designed to protect.

The recent decision of the Supreme Court of Canada in Mitchell ${ }^{10}$ illustrates the vulnerability of Aboriginal rights under the current framework of analysis. Further, the discussion of the concept of "sovereign incompatibility" by the minority in Mitchell suggests that the court may be at a turning point in its approach to $s$. 35. This article examines the risk posed to the future of Aboriginal cultures in Canada by the Court's current approach to $\mathrm{s}$. 35 claims. It considers the questions raised by the judgments in Mitchell regarding the future interpretation of s. 35. Finally, it suggests that the court should recognize that the Crown's fiduciary duty requires it to negotiate in good faith with Aboriginal groups the mechanisms necessary for the preservation of their cultures. In other words, the Crown's fiduciary duty of loyalty to Aboriginal peoples must carry with it an obligation to protect the distinctiveness of Aboriginal societies. The

2 See, e.g., R. v. Gladstone, [1996] 2 S.C.R. 723 [hereinafter Gladstone]; R. v. N.T.C. Smokehouse, [1996] 2 S.C.R. 672; and R. v. Van der Peet, [1996] 2 S.C.R. 507 [hereinafter Van der Peet] where the claim was characterized by the majority, at para. 76 , as a "right to exchange fish for money or other goods."

R. v. Pamajewon, [1996] 2 S.C.R. 821 [hereinafter Pamajewon].

Delgamuukw v. British Columbia, [1997] 3 S.C.R. 1010 [hereinafter Delgamuukw].

Mitchell, supra note 1.

Schedule B to the Canada Act 1982 (U.K.), 1982, c. 11 [hereinafter Constitution Act, 1982].

Van der Peet, supra note 2 at para. 31.

On the need for a case-by-case analysis in defining the scope of Aboriginal rights, see the comments of Lamer C.J.C. in Van der Peet, supra note 2 at para. 69; on the relevance of the common law tradition to the recognition of Aboriginal rights, see the discussion by McLachlin $J$. (dissenting) in Van der Peet, supra note 2 at paras. 260-75.

Delgamuukw, supra note 4 at 1123. See also R. v. Sparrow, [1990] I S.C.R. 1075 [hereinafter Sparrow] at 1105.

Supra note 1. 
recognition of such an obligation would offer meaningful protection to Aboriginal cultures, while remaining consistent with the Court's view of the purpose of s. 35 and the nature of the Crown's relationship with Aboriginal peoples in Canada.

\section{The Limitations of the Current Approach to Section 35}

The very survival of distinct Aboriginal societies in Canada until the twenty-first century may be considered a remarkable achievement given their past treatment under Canadian law. At various times, that law has encouraged the "enfranchisement" of Aboriginal persons, forcibly replaced traditional forms of government, banned the practice of certain Aboriginal customs, removed Aboriginal children from their families to residential schools off-reserve, restricted the ability of Aboriginal peoples to organize politically and to advance claims in court, effectively banned significant investments on reserves, and discounted Aboriginal ownership rights in the land that they occupied." In general terms, until recently Euro-Canadian religious and political institutions were uninterested in preserving Aboriginal languages, customs or cultures, with the result that most Aboriginal languages are now under threat of extinction. ${ }^{12}$ Since at least the 1970s, however, Canadian society has struggled to find a new balance that would leave more space for Aboriginal communities to thrive. The entrenchment of existing Aboriginal and treaty rights in the Constitution Act, 1982 was a major milestone in that journey.

Conscious of the importance of its role and the delicacy of the task at hand, the Supreme Court of Canada has tried to steer a middle course in interpreting s. 35 . The result has been a body of judgments as remarkable for the liberality of their general pronouncements as for the formal rigidity of the legal tests set out by the Court. On the one hand, the general principles set out by the Court have built a remarkably broad mantle of protection for Aboriginal claimants. Statutes and treaties are to be interpreted liberally and generously, with doubts to be resolved in favour of the Aboriginal claimant. ${ }^{13}$ Section 35 itself is to be interpreted flexibly, having regard to its "noble purpose" of reconciliation. ${ }^{14}$ The Crown owes a sui generis fiduciary duty in its dealings with Aboriginal people in which the "honour of the Crown" is always to be maintained. ${ }^{15}$ That duty extends so far as to limit the content of legislation that affects Aboriginal or treaty rights and the procedures followed by the Crown in adopting such legislation. ${ }^{16}$ In defining Aboriginal rights as well as treaty rights, the Aboriginal

For a review of the historical limitations placed on Aboriginal activities by Canadian law and federal policies, see, e.g., Royal Commission on Aboriginal Peoples, Report of the Royal Commission on Aboriginal Peoples (Ottawa: Ministry of Supply and Services Canada, 1996) [hereinafter RCAP Report], vol. 1 at 179-99, 263-313 and 333-82; and see J. Borrows, "Uncertain Citizens: Aboriginal People and the Supreme Court" (2001) 80 Can. Bar Rev. 15 at 16-19.

12 As of 1996, only three of Canada's 50 Aboriginal languages were considered secure from the threat of extinction. M.J. Norris, "Canada's Aboriginal Languages" (1998) Can. Social Trends 8 at 15-16.

13 Nowegijick v. The Queen, [1983] I S.C.R. 29 at 36; Sparrow, supra note 9 at 1106.

it See Sparrow, ibid. at 1106; Van der Peet, supra note 2 at para. 21; R. v. Adams, [1996] 3 S.C.R. 101 at para. 33 [hereinafter Adams].

is See Sparrow, ibid. at 1108.

16 Jbid. at 1113-19. 
perspective (including any Aboriginal legal perspectives) must be taken into account. ${ }^{17}$ General rules of evidence, although they apply to Aboriginal claims, must be interpreted flexibly so as to permit a fair consideration of the kinds of evidence most likely to be advanced in support of claimed Aboriginal rights. ${ }^{18}$

On the other hand, even the most cursory review of the s. 35 jurisprudence reveals the limitations of the current interpretive framework as a meaningful bulwark for the protection of the distinctiveness of Aboriginal societies. The purpose of s. 35, in the view of the Court, is, as noted above, the reconciliation of the historical fact of the flourishing of distinct Aboriginal societies at the time when Europeans began to settle in this country with the existence of a sovereign, mostly non-Aboriginal Canada today. Yet the reconciliation contemplated by the current approach of the Court is limited to a balancing of those distinctive Aboriginal customs, traditions and practices that can be proved to have existed prior to contact, with legislation and non-Aboriginal activities as they exist today. ${ }^{19}$ The rationale for the focus on pre-contact activities to define what is distinctively Aboriginal today is perhaps understandable. However, the result of this approach (even granting that pre-contact activities may evolve and still receive protection ${ }^{20}$ ) can only be to circumscribe the elements of Aboriginal culture that will qualify as even prima facie entitled to legal protection. Further, the approach involves a double standard in two separate ways. First, the "reconciliation" does not limit the activities or economic interests that are permitted to justify intrusion on Aboriginal rights $^{21}$ in the same way, namely to those that were central to European societies at the time of contact. Second, the approach (particularly insofar as it relates to jurisdictional and governance claims) is inconsistent with the dynamic, "living tree" analysis used by the courts in defining federal and provincial jurisdictions under ss. 91 and 92 of the Constitution Act, $1867 .^{22}$ The inconsistency is not haphazard: it would be virtually impossible for modern governments to act in the interests of their citizens if they were limited to the tools they had available four hundred years ago. This is particularly true of the protection of culture: consider the consequences if Quebec's constitutional powers to sustain its culture were limited to regulating those activities that were "central" to the "distinctive" French-Canadian society when the British first interacted with the French in North America.

Further, if contemporary Aboriginal rights are to be determined by reference to a date in the past, it is not clear why the time of "contact" with Europeans should be

See, e.g., ibid. at 1112; R. v. Marshall, [1999] 3 S.C.R. 456 at para. 19 and Van der Peet, supra note 2 at para. 49 . On the significance of the Aboriginal legal perspective, see Delgamuukw, supra note 4 at para. 112.

See Delgamuukw, ibid. at 1066-76.

The test used by the court was set out by Lamer C.J.C. in Van der Peet, supra note 2 at para. 46. Aboriginal practices and customs will receive constitutional protection even though they may have evolved over the time since contact: Sparrow, supra note 9 at 1093. Sparrow, ibid. at 1113-19 and Gladstone, supra note 2 at 762-80.

(U.K.), 30 \& 31 Vict., c. 3, reprinted in R.S.C. 1985, App. II, No. 5. See A.G. Ontario v. A.G. Canada, [1947] A.C. 127 at 154 (P.C.); and Reference re Secession of Quebec. [1998] 2 S.C.R. 217 at para. 52 [hereinafter Reference re Secession of Quebec]. See also P.W. Hogg, Constitutional Law of Canada, 4th ed. (Scarborough: Carswell, 2002) at 397-98 [hereinafter Hogg]. 
considered the most relevant one. ${ }^{23}$ If the purpose of s. 35 is to preserve only those aspects of Aboriginal culture that can be said to be unadulterated by European influence, then the effect is not just to exclude habits and customs that respond to the new realities of contemporary life. It is also to define the essence of Aboriginal cultures from a conceptual perspective in a pristine, hermetically sealed manner that would never be considered adequate to define the essence of "Canadian," "Quebecois" or any other culture today. ${ }^{24}$ The court is clearly aware of this problem and its members have struggled in the past with the implications of protecting today only those aspects of Aboriginal society that remain after all external and modern influences have been removed. ${ }^{25}$ Without dwelling further on the conceptual problem raised here, it is clear that in practice the choice of the time of contact as the relevant date for defining protected Aboriginal rights (as opposed to the time Britain or Canada asserted sovereignty in the area, ${ }^{26}$ or later) has effectively eliminated protection of Aboriginal activities that arose or became prominent through interaction with European society. ${ }^{27}$

A related limitation of the court's approach to Aboriginal rights is its requirement that claimed rights relate to "practices, customs or traditions" ${ }^{28}$ prevalent at the time of contact. The focus on a particular activity leads inevitably to question-begging definitional debates as to how narrowly to define the "activity" on which the contemporary Aboriginal claim is based. Here too the Court has recognized the conceptual problem and, unsurprisingly, advised that the claimed right must be defined neither too broadly nor too narrowly. ${ }^{29}$ Nevertheless, the result is that the scope of the recognized right in a particular case will frequently depend on what may appear to be an arbitrary process of characterizing the traditional "activity" in question. In Van der Peet, for example, the traditional activity of the Sto:lo Nation for the purpose of s. 35 analysis could have been "fishing for salmon," "fishing salmon for food or for social or ceremonial purposes," "making a modest livelihood from the fruits of the Fraser River" or "taking advantage of the resources of the Fraser River," each of which may appear to be an equally reasonable characterization of the same historical activity, and each of which will lead to a different result if recognized for protection under s. $35 .^{30}$

This point is noted by McLachlin J. (dissenting) in Van der Peet, supra note 2 at para. 247. For further criticism of the choice of time of contact to define Aboriginal rights see J. Borrows, "The Trickster: Integral to a Distinctive Culture" (1997) 8 Constitutional Forum 27; L. Rotman. "Creating a Still Life Out of Dynamic Objects: Rights Reductionism at the Supreme Court of Canada" (1997) 36 Alta. L. Rev. 1; and B. Slattery, "Understanding Aboriginal Rights" (1987) 66 Can. Bar Rev. 727 at 746 [hereinafter "Understanding Aboriginal Rights"].

See, e.g., the judgment of L'Heureux-Dubè J. in Van der Peet, supra note 2 at para. 154.

The date used by the court for determining the existence of an Aboriginal title claim under s. 35 . See Delgamuukw, supra note 4 at para. 143.

See, e.g., Van der Peet, supra note 2 at para. 13, where the evidence showed a significant trade between the Sto:lo First Nation and the Hudson's Bay Company prior to the assertion of British sovereignty in the area. This evidence was ruled irrelevant to the commercial fishing claim asserted because it related to an era after initial contact.

Ibid. at para. 45.

Ibid. at para. 50.

In Van der Peet, ibid., the Court divided as to the relevant characterization of the right claimed. For Lamer C.J.C., at para. 91, it was a claim for "the right to exchange fish for money or other goods"; for L'Heureux-Dubé J., at para. 96, it included "the right to sell, trade and barter fish for livelihood, support and sustenance purposes"; and for McLachlin J.. at para. 224, it was simply the right to "sell fish caught in the Fraser River." 
What are the jurisprudential considerations that should determine the correct choice? The Court's dilemma is real, and the Court appears conscious that the choice made in a particular case can appear unconvincing on the grounds of logic alone.

Whether or not the Court's approach to conceptualizing traditional activities and practices is capable of producing reasonable, practical results for claims related to the harvesting of fish or wildlife by Aboriginal peoples, it has so far proved inapt for the recognition of Aboriginal traditions of governance and management. In part, this results from the Court's approach to the conceptualization problem described above. In Pamajewon, ${ }^{31}$ for example, if the Aboriginal claim to regulate casino gambling on the reserve had been characterized by the Court as an assertion of a right "to manage social and economic activities" on the First Nation's territory, the claim could not have been dismissed on the basis of a dearth of evidence that at contact the practice of high stakes gambling ${ }^{32}$ was central to the First Nation's distinctive culture. Moreover, as Peter Hogg has pointed out, quite apart from the conceptualization problem, an "activities" test seems singularly inappropriate for governance claims. ${ }^{33}$ If protection of free speech is integral to the traditions of Canadian society, for example, it is a tradition that could scarcely be protected at all if that protection were limited to the types of communicative activities that dominated Canadian society in the past. One might respond that traditions of governance or resource management are simply not suited for protection as Aboriginal rights under s. 35, as the Supreme Court has suggested. ${ }^{34}$ But surely such a conclusion should be based on a reasoned interpretation of s. 35, rather than on a mere statement to the effect that to claim protection for those traditions is to assert Aboriginal rights at too general a level, as the Court indicated in Pamajewon ${ }^{35}$ and in Delgamuukw. ${ }^{36}$ Recall that the basis of Aboriginal rights is the fact that Aboriginal peoples were here first, "organized in societies," as Judson J. stated in $R$. v. Calder. ${ }^{37}$ If the premise of the $s .35$ jurisprudence is to recognize the place of Aboriginal peoples in the history of this country, and if its purpose includes protecting what is distinct about and integral to Aboriginal societies, it is difficult to see how $\mathbf{s}$. 35 can have enduring impact if it is interpreted to exclude the mechanisms that permit a society to pass on its distinctive features. In short, a test that protects certain traditional activities, and ignores the mechanisms necessary to sustain Aboriginal languages and cultures, risks leaving s. 35 without separate ways of life to reconcile.

Supra note 3 at 834.

Ibid. at para. 26. Lamer C.J.C. adds, at para. 29: "I ... agree with the observation made by Flaherty Prov. Ct. J. ... commercial lotteries such as bingo are a twentieth century [phenomenon] and nothing of the kind existed among Aboriginal peoples and was never part of the means by which these societies were traditionally sustained or socialized."

Hogg, supra note 22 at 593 .

Delgamuukw, supra note 4 at 1115 . The $R C A P$ Report, of course, took a different view: see $R C A P$ Report, supra note 11 at $200 \mathrm{ff}$.

Supra note 2 at 835.

Supra note 3 at para. 170.

Calder v. Attorney General of British Columbia, [1973] S.C.R. 313 at 328. See also Van der Peet, supra note 2 at para. 30 per Lamer C.J.C.: "the doctrine of aboriginal rights exists and is recognized and affirmed by s. 35(1), because of one simple fact: when Europeans arrived in North America, aboriginal peoples were already here, living in communities on the land. and participating in distinctive cultures, as they had done for centuries." 
Finally, the jurisprudence under s. 35 to date has required that each Aboriginal community bring a separate claim with respect to each defining feature of its society for which it seeks protection. There are conceptual reasons for this approach, of course, including the diversity of Aboriginal cultures in Canada. The court may also be motivated by a prudent reluctance, long rooted in common law practice, to make decisions with implications beyond the facts of the case before it. In particular, in relation to governance traditions, the court may be concerned not to make decisions that would have broad, unknown implications for current jurisdictional arrangements in Canada - an issue to which we will return shortly in reviewing the decision in Mitchell. Still, the result is a heavy burden of litigation on individual Aboriginal communities to establish their rights, and a group-specific "patchwork" of separate recognized Aboriginal rights across the country. Such a patchwork approach is also not conducive to broad protection for Aboriginal cultures, languages and social frameworks, without which recognition of particular harvesting practices will have little meaning.

There is an approach to Aboriginal rights that would offer protection for the sustaining of Aboriginal cultures, and that at the same time would be consistent with the purpose of s. 35 and the broad lines of the Supreme Court's jurisprudence to date. Before outlining that approach, however, it will be helpful to review the court's most recent Aboriginal rights decision.

\section{MITCHELL V. M.N.R.}

The court's decision in Mitchell in 2001 is a useful illustration of the main themes discussed above. On the one hand, the majority judgment, written by McLachlin C.J.C., can be seen as a straightforward application of the traditional test for Aboriginal rights. On the other, the minority concurring judgment issued by Binnie J. offers insight into continuing concerns by members of the Court about Aboriginal assertions of autonomy as a right protected by s. 35 .

The facts in Mitchell raised difficult issues for the courts. Grand Chief Michael Mitchell (also known as Kanentakeron) is a Mohawk from Akwesasne, a First Nation community near Cornwall, Ontario. Akwesasne is a territory that now finds itself straddling two different borders: the United States-Canada international border and the Quebec-Ontario provincial border. As a result, quite apart from any Aboriginal government authority at Akwesasne, five different American and Canadian governments claim their own jurisdictions over different parts of the territory. In 1988 Grand Chief Mitchell crossed the international border from the United States into Cornwall. He brought ten blankets, twenty Bibles, a case of motor oil, food, some used clothing, a washing machine, ten loaves of bread, four gallons of milk, six bags of cookies, two pounds of butter and twelve cans of soup, all of which he had purchased in the United States. All but the motor oil was later presented as a gift to another Mohawk community in Ontario. The oil was offered for resale to Akwesasne community members at a store in Akwesasne. Grand Chief Mitchell had declared the goods to Canada Customs, but asserted that he had an Aboriginal right to enter Canada from the United States with personal and community goods for trade with First Nations without paying customs and other duties. 
After hearing evidence of pre-contact Mohawk trading, the trial judge applied the Van der Peet test and ruled that, subject to certain specified limitations, Grand Chief Mitchell had established an Aboriginal right to bring goods into Canada duty-free for "non-commercial scale trade" with other Aboriginal communities. ${ }^{38}$ The Federal Court of Appeal affirmed the trial judgment. ${ }^{39}$ The Supreme Court of Canada, however, unanimously overturned the decisions of the courts below. For the seven judges in the majority, McLachlin C.J.C. ruled that the evidence did not support a finding that trade across the St. Lawrence River had been a defining feature of Mohawk society prior to contact with Europeans in 1609. Therefore, applying the Van der Peet test, Grand Chief Mitchell had failed to establish an Aboriginal right. Justices Binnie and Major concurred, but also concluded that the doctrine of "sovereign incompatibility" would have prevented any such right from being recognized regardless of any evidence of Mohawk traditions.

The judgments in Mitchell demand recognition as much more than a straightforward application of an objective test for the recognition of Aboriginal rights. Although the result is perhaps unsurprising, the majority's reasons point out once again the tenuousness of the current test as a possible support for the general protection of what is distinctive about Aboriginal societies. For its part, the minority judgment offers new insight into what may be generally held concerns by members of the Court about Aboriginal assertions of autonomy as a right protected by s. 35 .

\section{A. THE MAJORITY JUdGMENT}

Much of the majority judgment focuses on the appropriate treatment of evidence in Aboriginal claims and on the Court's reasons for concluding that the trial judge had been overly generous in his interpretation of the evidence in relation to historical northsouth Mohawk trade practices. Noteworthy too is the majority's treatment of the three elements of the Van der Peet test discussed above: the logical challenges involved in determining how to characterize the scope of the right at issue, the restrictiveness of focusing only on defining features of pre-contact Aboriginal society, and the inflexibility of relying on an activities test alone to define the kinds of Aboriginal rights that are protected by s. 35 .

The court's characterization of the nature of the claimed right is a pivotal conclusion in virtually all Aboriginal rights cases. Its specificity determines the content of the historical evidence that will be considered probative of the right. It affects whether the concept described can be said to be "integral" to and a "defining feature" of the Aboriginal society prior to contact. It colours the analysis of whether such a right can be said to have been clearly and plainly extinguished by conflicting legislation prior to the coming into force of s. 35. Finally, it will influence the court's analysis of whether 
subsequent legislation infringing that right can be justified by the Crown. ${ }^{40}$ To appreciate this, it is necessary to consider only how different the court's analysis would have been in Pamajewon if the s. 35 claim there had been defined as a right "to manage economic activities within the community," rather than to engage in "high stakes gambling."

In Mitchell, McLachlin C.J.C. begins by noting that the nature of the right claimed cannot be defined purely by the characterization offered by the Aboriginal claimant, nor can it be inferred solely from the event that gave rise to the litigation. That event "merely represents an alleged exercise of an underlying right; it does not, in itself, tell us the scope of the right claimed." To ascertain the "true nature" of the claim, she turns to three factors first set out by the Court in Van der Peet: ${ }^{42}$

(1) the nature of the action which the applicant is claiming was done pursuant to an aboriginal right;

(2) the nature of the governmental legislation or action alleged to infringe the right. i.e. the conflict between the claim and the limitation; and the ancestral traditions and practices relied upon to establish the right. ${ }^{43}$

The Court does not downplay the importance of the characterization process. According to McLachlin C.J.C., "An overly narrow characterization risks the dismissal of valid claims and an overly broad characterization risks distorting the right by neglecting the specific culture and history of the claimant's society." 44

In the end, the majority characterized the claimed right in Mitchell as "the right to bring goods across the Canada-United States boundary at the St. Lawrence River for the purposes of trade." ${ }^{45}$ That description was somewhat different than the right claimed by Grand Chief Mitchell, namely the right to bring personal and community goods from the United States to Canada, exempt from duty, and the right to trade those goods with other First Nations. ${ }^{46}$ In applying the first of the factors listed above (the nature of the action in question) the majority focused largely on the claimant's characterization of what he had done: bring goods across the border in accordance with traditional Mohawk trading practices. With respect to the second factor (the law in conflict with the alleged right), the provisions of the Customs $\mathrm{Act}^{47}$ did not suggest a different characterization of the claimed right. The third factor (the relevant traditions and practices of the Aboriginal group) here pointed to the Mohawks' traditions of trade

In accordance with the justification test first set out in Sparrow, supra note 9 at 1113 . Note the court's most recent statement of the types of legislative objectives that might justify infringing a s. 35 right (at least in the context of Aboriginal title claims) as set out in Delgamukw, supra note 4 at para. 165 . It can be argued that the relatively expansive list of valid legislative objectives set out in Delgamuukw' should be applied with caution outside the context of Aboriginal title claims.

$\$ \quad$ Mitchell, supra note 1 at para. 14.

s: Van der Peet, supra note 2 at para. 53.

4 Mitchell, supra note I at para. 15.

I4 Ibid.

ts Ibid. at para. 19.

46 Ibid. at para. 16.

7 Customs Act, R.S.C. 1985 c. 1 (2d Supp.). 
and commerce. The majority declined to limit the claimed right, as suggested by Grand Chief Mitchell and determined by the courts below, to a right to import goods for trade with other First Nations, noting the practical impossibility of ensuring that goods so imported would not ultimately be resold to others. The majority also refused to limit the right under consideration to a right to engage in "small, non-commercial scale trade" as the lower courts had done. That qualification was not one that had been sought by the claimant at trial, and it obviously posed definitional difficulties. ${ }^{48}$

The trial judge in Mitchell had found that trade was a central, distinguishing feature of the Iroquois in general, and the Mohawks in particular, and that the Mohawks had travelled on occasion across the St. Lawrence River. ${ }^{49}$ However, defining the claimed right as a right to trade across the border at the St. Lawrence, the majority disagreed with the trial judge's conclusion that the evidence at trial was sufficient to substantiate such trade as a defining characteristic of Mohawk society prior to contact. ${ }^{50}$

The majority's characterization of the claimed right in Mitchell does not seem unreasonable, but it is difficult to deny that the three guiding factors used by the court do not lead inexorably to the characterization reached by the Court, in Mitchell, or in any other case. The nature of any physical action must be determined by whatever context the Court considers relevant. Here, the majority focuses on the importance of the border to Grand Chief Mitchell's asserted claim, and the claimant's assertion that the purpose of his act related to trade. In other cases, the claimant's own description of the nature of the claim has not garnered the same respect. ${ }^{51}$ In any event, the generalization from one physical act to the most appropriately characterized communal right that might be said to be signified by that act is a process that in many cases will be so uncertain as to appear arbitrary. The second factor, the nature of the legislation in conflict with the assertion, is clearly arbitrary from the Aboriginal perspective and, by its focus on a particular regulatory prohibition, is likely to narrow the characterization of the claimed right. The third factor, the ancestral traditions and practices relied upon by the claimant, must also be defined by whatever the Court considers to be the relevant criteria for defining the "tradition" said to be in continuity with the contemporary act. In that sense this factor is no more an external indicator of the nature of the claimed right than the first factor.

The majority judgment also illustrates the significance of the Court's focus on the time of contact in adjudicating Aboriginal rights claims. In Mitchell there was considerable evidence at trial of the important role played by the Mohawks in the northsouth fur trade across the St. Lawrence after Europeans arrived in the area in the early 1600 s. However, this evidence, together with references to trade in early treaties between the British Crown and the Iroquois, was simply not probative for the court because the date of European arrival in the area was the cut-off point for identifying traditions central to Mohawk society. ${ }^{52}$ 
More generally, the majority judgment in Mitchell confirms the tenuousness of relying solely on ancestral activities to extrapolate what should be recognized as existing Aboriginal rights. While an activities test appears logical in the context of traditional harvesting rights claims, there seems little reason to definitively circumscribe all other existing Aboriginal rights to a continuance of physical practices that once formed important aspects of an Aboriginal society. Equally, it does not necessarily follow that any prevalent ancestral activity should found a currently protected communal right, ${ }^{53}$ regardless of the nature of the activity or its current suitability for constitutional recognition.

\section{B. THE MiNORITY JUdGMENT}

This last point, that not all ancestral activities may be suitable for constitutional protection, is the focus of the concurring reasons of Binnie J. in Mitchell. For Binnie $\mathrm{J}$., the essence of the claim in Mitchell was for an international mobility right that he considered inconsistent with Canadian sovereignty. Thus, in his view, regardless of what the evidence might have shown about traditional Mohawk society and its customs, Canadian law (and before that British colonial law) could never have recognized Mohawk mobility practices as giving rise to an enforceable legal right. ${ }^{54}$ Such a right would be incompatible with the sovereignty of Canada, which like every nation requires the authority to control mobility across its borders. ${ }^{s 5}$

Justice Binnie's analysis will no doubt disturb those who are already concerned about the existing limitations that have been placed on the recognition of Aboriginal rights under s. 35 and the breadth of the legislative objectives that may be relied on to override such rights. The majority judgment expressly declines to comment on the validity of an additional "sovereign incompatibility" limitation on the scope of Aboriginal rights. ${ }^{56}$ Still, the potential implications for Canadian sovereignty of recognizing Aboriginal autonomy rights are unlikely to have been far from the Court's mind in governance cases like Pamajewon, and it is perhaps well (even for the Aboriginal cause) that they have now been raised explicitly by at least two members of the Court. Indeed, an open discussion of Binnie J.'s concerns may be helpful in triggering a fresh look at the potential of s. 35 to safeguard Aboriginal autonomy.

Justice Binnie is careful to indicate in his reasons that he does not intend to foreclose (or to endorse) any arguments with respect to the compatibility of "internal" Aboriginal self-governing institutions with Canadian sovereignty. ${ }^{57}$ In addition, he suggests that the concept of sovereign incompatibility should be used sparingly.$^{58}$ Still, he expresses concern that some ancestral activities, like "raising private armies," should not be

Subject, of course, to valid government infringement in accordance with the justification test first set out in Sparrow, supra note 9 at 1113.

Mitchell, supra note 1 at $990-91$.

Ibid. at $989-90$.

Ibid. at para. 64.

Ibid. at para. 165.

Ibid. at paras. 151, 154. 
considered to require justification to be overridden in Canada today. ${ }^{59}$ Justice Binnie cites Slattery's formulation of the relevant principle as follows:

\begin{abstract}
When the Crown gained sovereignty over an American territory, colonial law dictated that the local customs of the native peoples would presumptively continue in force and be recognizable in the courts, except insofar as they were unconscionable or incompatible with the Crown's assertion of sovereignty. ${ }^{60}$
\end{abstract}

Because of the importance of border control to modern nations, Binnie J. concludes that ancestral international mobility rights are in fact the kind of rights that are incompatible with Crown sovereignty.

It is Binnie J.'s disquisition on the implications of Canadian sovereignty for Aboriginal rights that is likely to raise heated discussion. He argues that the relationship between Aboriginal peoples in Canada and the Crown has led to a "merged" or "shared" sovereignty, which must include "at least the idea that Aboriginal and nonAboriginal Canadians together form a sovereign entity with a measured common purpose and united effort." ${ }^{61}$ By this reasoning, he concludes, "aboriginal peoples do not stand in opposition to, nor are they subjugated by, Canadian sovereignty. They are part of it." ${ }^{62}$ Such a perspective would likely be embraced by many Canadians, nonAboriginal and Aboriginal alike. Indeed, counsel for the claimant in Mitchell apparently urged judicial recognition of Mohawk autonomy within the broader framework of Canadian sovereignty. ${ }^{63}$

In describing the evolution of Crown-Aboriginal relations, the minority reasons refer to the "Two-Row Wampum," the treaty symbol used repeatedly by the British and the Iroquois from the seventeenth century on to symbolize their relationship. The Two-Row Wampum, or Gus-Wen-Tah, represented the Indian people and the British, each in their own vessel, living in respect for each other's laws, customs and ways. ${ }^{64}$ However, at times the minority's treatment of shared sovereignty seems to focus on the relationship from the perspective of the Crown partner alone. A treaty right, for example, is described as "itself an expression of Crown sovereignty." ${ }^{\text {"As }}$ And the capacity of each side to sustain its own laws and traditions does not receive much attention in the balance of the minority reasons, which focus largely on British assertions of sovereignty and the content of British colonial law, even though colonial common law is

3y Ibid. at paras. 152-53.

6) "Understanding Aboriginal Rights," supra note 24 at 738, as cited in Mitchell, supra note 1 at para. 141.

6) Mitchell, ibid. at para. 129.

$\therefore \quad$ Ibid. at para. 135 .

(1) Ibid. at para. 113.

(4) Ibid. at paras. 127-28 per Binnie J. See also J. Borrows, "Wampum at Niagara: The Royal Proclamation, Canadian Legal History and Self-Government" in M. Asch, ed., Aboriginal and Treaty Rights in Canada (Vancouver: University of British Columbia Press, 1997) 155 [hereinafter "Wampum at Niagara"].

65 Mitchell, ibid. at para. 139 [emphasis added]. 
acknowledged to be only one of several sources of the existence of Aboriginal rights. ${ }^{60}$ The Court has made it clear in the past that Aboriginal rights derive from the prior presence of Aboriginal societies in this country and from the laws and traditions of both societies. ${ }^{67}$ As such, according to Lamer C.J.C., quoting Slattery, "The law of Aboriginal rights is neither English nor Aboriginal in origin: it is a form of intersocietal law that evolved from long-standing practices linking the various communities." ${ }^{168}$ It is for this reason that Aboriginal rights must be understood from both perspectives. ${ }^{69}$

The minority reasons repeatedly refer to the concept of "shared" or "merged" sovereignty as one that was advocated by the Royal Commission on Aboriginal Peoples. The concept of merger as used by the minority, however, is different from sharing. Canada's Constitution is federal, reflecting a commitment to shared but separate jurisdictions between provinces and the national government. Canada's internal sovereignty, in other words, is not unitary. In using the phrase "shared sovereignty" to describe its concept of Aboriginal governance, the Royal Commission clearly intended it in the federal sense. "Shared sovereignty," according to the Commission, "is a hallmark of the Canadian federation and a central feature of the three-cornered relations that link Aboriginal governments, provincial governments and the federal government." ${ }^{\text {"0 }}$ The distinction between a concept of merged sovereignty that reflects only the sovereignty of the Crown, subject to treaties and a respect for essential traditional activities, and the concept of a shared sovereignty, in which space is left for the capacity of Aboriginal societies to sustain themselves, is a critical one, yet one that is largely glossed over in the minority judgment. ${ }^{71}$

The minority's main point, of course, is that in its view a broad international mobility right for Aboriginal people cannot be reconciled with any practical vision of Canadian sovereignty, including the shared sovereignty concept endorsed by the Royal Commission. In that context, it is perhaps unsurprising that the judgment should focus on the needs of the Canadian polity at large. Still, the issue of balance is a critical one

G

Ibid. at paras. 142-44, per Binnie J. Aboriginal rights need not have been recognized by the sovereign or by the common law prior to 1982 in order to receive protection under s. 35. Adams, supra note 14; R. v. Côté, [1996] 3 S.C.R. 139; and Delgamuukw, supra note 4 at para. 136. See Delgamuukw, supra note 4 at paras. 112, 126; Sparrow, supra note 9 at 1094; and Guerin v. Canada, [1984] 2 S.C.R. 335 at 376 [hereinafter Guerin].

68 Van der Peet, supra note 2 at para. 42, quoting B. Slattery, "The Legal Basis of Aboriginal Title," in F. Cassidy, ed., Aboriginal Title in British Columbia: Delgamuukw v. The Queen (Lantzville: Oolichan Books, 1992) at 120-21.

See Delgamuukw, supra note 4 at para. 81; and Van der Peet, supra note 2 at 546-51. On the sources of Aboriginal rights, see B. Slattery, "Making Sense of Aboriginal and Treaty Rights" (2000) 79 Can. Bar Rev. 196.

RCAP Report, supra note 11, vol. 2 at $240-41$, as cited by Binnie J. in Mitchell, supra note 1 at para. 130. For a similar view of the sharing of sovereignties in relation to Aboriginal peoples, see B. Slattery, "The Organic Constitution: Aboriginal Peoples and the Evolution of Canada" (1996) 34 Osgoode Hall L.J. 101 at 109.

Note, for example, the references by Binnie J. to "European (now Canadian) sovereignty," to the new "European-based constitutional order" and, generally, to the need for Aboriginal people to accept Canadian sovereignty without reciprocal indication of how "Canadian" sovereignty should be considered to have adapted for its part in its merger with Aboriginal sovereignty: Mitchell, supra note 1 at 957,985 . 
for the continued formulation of a broader, workable view of the Aboriginal rights protected by s. 35 . Arguably, the basis of such a balance can be found, at least by inference, in the logic of the minority's reasons. In the course of his judgment Binnie J. cites the Royal Commission's formulation of the concept of shared sovereignty in more detail:

On this view, to return to the nautical metaphor of the "two-row" wampum, "merged" sovereignty is envisaged as a single vessel (or ship of state) composed of the historic elements of wood, iron and canvas. The vessel's components pull together as a harmonious whole, but the wood remains wood, the iron remains iron and the canvas remains canvas. Non-Aboriginal leaders, including Sir Wilfrid Laurier, have used similar metaphors. It represents, in a phrase, partnership without assimilation. ${ }^{72}$

Partnership without assimilation lies at the basis of any reconciliation, and reconciliation, as Binnie J. notes, is the purpose of $s$. 35 and the touchstone for resolving any claim of Aboriginal rights. ${ }^{73}$ If, as the minority reasons assert, Aboriginal peoples are not in fact to be subjugated by a modern vision of Canadian sovereignty, and if they are to be capable of continuing to "live and contribute as part of our national diversity," ${ }^{74}$ and if indeed s. 35 is to continue to have meaning long into the future, it follows that shared sovereignty must leave space for Aboriginal cultures to sustain themselves.

The minority reasons in Mitchell cite with approval the statement of McLachlin J. in Van der Peet, that the Aboriginal rights question focuses on the "laws and customs [that] held sway before superimposition of European laws and customs." 75 A priori, fundamental to such laws and customs were that they were mechanisms for ensuring the continuation of their societies. It may be suggested that therein lies the key, unelaborated in Mitchell, to a fuller, more coherent protection of Aboriginal rights within Canadian society at large.

\section{A NEW CONCEPTION OF the Fiduciary Relationship Between the Crown and aboriginal Peoples}

As we have seen, the minority judgment in Mitchell can be read as positing the next major limitation to the recognition of Aboriginal rights: concerns about "sovereign incompatibility." However, it can also be read as pointing the way to a new development in s. 35 jurisprudence. Since its 1973 decision in Calder ${ }^{76}$ the Supreme Court of Canada has struggled to give meaning to Aboriginal rights without undermining the legal or financial fabric of the country. The Court has been creative in its choice of tools, which have included a broad purposive approach to s. 35, flexibility in the treatment of evidence, a conscious effort to take into account the Aboriginal perspective on particular transactions and on the relationship with the Crown in general, and, most importantly, the recognition of a general fiduciary duty owed by 
the Crown in its dealings with Aboriginal peoples and their lands. However, even with these principles in place, the current requirement of a claim-by-claim approach, whatever its merits, will leave the contours of Aboriginal entitlements uncertain for several decades as claims wend their way through the courts.

In response, the Court has repeatedly encouraged negotiations to resolve Aboriginal rights claims. ${ }^{77}$ Negotiated outcomes allow the parties to find flexible, enduring solutions to the issues in a complex modern context. These solutions can take into account third-party interests, can address the parties' concerns in a more global fashion than a court judgment, and can be debated and ratified by the parties themselves. The past twenty years have seen some progress in negotiated solutions of specific Aboriginal claims, particularly in the context of claims to lands and resources. ${ }^{78}$ However, progress to date has been sporadic. Federal annual claims budgets are limited, forcing larger claims to court, and the parties have not been able to agree on effective dispute resolution mechanisms where there are good faith disagreements that lead to impasse. ${ }^{79}$ In addition, outside of British Columbia and Saskatchewan, no effective agreement exists between the federal and provincial governments as to the process by which they will co-operate in the resolution of Aboriginal claims. Finally, lack of clarity as to the general extent of Aboriginal rights, particularly in relation to claims for rights of governance, has meant that Aboriginal claimants often lack bargaining power in the negotiations. In the result, the latest federal assessment indicates that some 750 filed claims remain unresolved. ${ }^{80}$ Negotiation of governance arrangements to date has progressed even more slowly. ${ }^{81}$

Finally, we have seen that the Van der Peet test, as currently applied, is particularly ill-suited to recognizing governance rights. Requiring each First Nation to establish that they have a modern governance practice that has a reasonable degree of continuity with a specific pre-contact practice that formed at that time a defining feature of its society, cannot conceivably lead to meaningful national protection of contemporary Aboriginal cultures. Yet that is the purpose of s. 35. The Supreme Court has frequently pointed out that Aboriginal rights must be seen as "rights not relics." 82 As Binnie J. indicated in Mitchell, Aboriginal rights "are projected into modern Canada where they are exercised as group rights in the 21 st century by modern Canadians who wish to preserve and protect their Aboriginal identities." ${ }^{83}$

See, e.g., Delgamuukw, supra note 4 at para. 186 per Lamer C.J.C., and at 1207 per La Forest J. See also Sparrow, supra note 9 at 1105.

See also the website for Indian and Northern Affairs Canada, Agreements - Indian and Northern Affairs Canada, online: Indian and Northern Affairs Canada <www.ainc-inac.gc.ca/pr/agr/ index_e.html> (date accessed: 19 February 2003).

The current annual national federal budget for settement of all specific claims (for breaches of treaty or other specified Crown legal obligations, excluding Aboriginal title claims) is $\$ 75$ million. Negotiations to establish a new independent claims resolution process have been ongoing since 1991, thus far without result.

See the website for Indian and Northern Affairs Canada, National Mini Summary - Specific Claims Branch, online: Indian and Northern Affairs Canada <www.ainc-inac.gc.ca/ps/clm/ nms_e.html> (date accessed: 19 February 2003).

See supra note 78.

Mitchell, supra note I at para. 132.

Ibid. 
It is submitted that a logical way for the Court to resolve this conundrum, while respecting the principles of $\mathrm{s}$. 35 jurisprudence to date, is for it to recognize that the Crown's fiduciary relationship with Aboriginal peoples requires it to negotiate a protected space for the Aboriginal institutions necessary to permit the survival of Aboriginal societies.

The fiduciary duty of the Crown toward Aboriginal peoples was first recognized in Guerin v. $R^{84}$ In that case, which involved the leasing of Musqueam First Nation lands in Vancouver, Dickson J. concluded that the nature of Indian title and the framework of the federal statutory scheme for disposing of Indian land placed upon the Crown a fiduciary duty to deal with such land for the benefit of the Indians. ${ }^{85}$ The basis of the duty was the confirmation in the Indian Act of "the historic responsibility which the Crown has undertaken, to act on behalf of the Indians so as to protect their interests in transactions with third parties." ${ }^{86}$ The duty is a sui generis one which is "in the nature of a private law duty," notwithstanding that it may apply to the administrative and legislative functions of the government. ${ }^{87}$

Six years later, in Sparrow, ${ }^{88}$ the Supreme Court of Canada enunciated a broader conception of the fiduciary duty, this time in the context of an Aboriginal rights claim pursuant to s. 35. In a unanimous judgment, after reviewing the history of CrownAboriginal relations in Canada, the Court stated as follows:

In our opinion, Guerin, together with R. v. Taylor and Williams (1981) 34 O.R. (2d) 360, ground a general guiding principle for s. 35(1). That is, the government has the responsibility to act in a fiduciary capacity with respect to Aboriginal peoples. The relationship between the Government and Aboriginals is trust-like, rather than adversarial, and contemporary recognition of Aboriginal rights must be defined in light of this historic relationship. ${ }^{89}$

In Sparrow, the Court established a justification test that must be applied to any legislation that infringes Aboriginal rights. In elaborating that test, the Court said

There is no explicit language in the provision [s. 35] that authorizes this court or any court to assess the legitimacy of any government legislation that restricts Aboriginal rights. Yet we find that the words "recognition and affirmation" incorporate the fiduciary relationship referred to earlier and so import some restraint on the exercise of sovereign power. ${ }^{90}$

The Court in Sparrow explicitly tied the recognition of the Crown's fiduciary duty to the exercise of Crown sovereignty and legislative power and the history of CrownAboriginal relations." ${ }^{91}$ To return to the sovereignty issues discussed by Binnie J. in

Ibid. 
Mitchell, there is no doubt that Aboriginal peoples exercised internal sovereignty both prior to and after contact with Europeans. Indeed, their autonomy with respect to their internal affairs was recognized by the British Crown. ${ }^{92}$ As Lamer J. noted for a unanimous court in $R$. v. Sioui (referring to British-Aboriginal relations in the mideighteenth century) "the Indian nations were regarded in their relations with the European nations which occupied North America as independent nations ... [The British Crown] also allowed them autonomy in their internal affairs, intervening in this area as little as possible." ${ }^{93}$ The use of the Two-Row Wampum at the treaty ceremony in Niagara in 1764, for example, was acknowledged by the ranking British colonial official to be antithetical to the notion that the Chiefs involved had intended to submit to British sovereignty over their internal affairs. ${ }^{94}$

It has been argued that the tradition of Aboriginal autonomy prior to contact requires that self-government should be recognized as an Aboriginal right enforceable under $\mathrm{s}$. $35 .^{95}$ This is a conclusion that the Supreme Court has yet to accept. At the least, however, the subsequent assertion of Crown legislative jurisdiction over the internal affairs of Aboriginal peoples (most significantly through the detailed regulatory scheme of the Indian $A c t^{96}$ ), and the resultant vulnerability of Aboriginal cultures to the discretion of the Crown, must be subject to the Crown's fiduciary duty to protect the interests of the Aboriginal peoples involved. That duty, it is submitted, includes the duty to preserve a space for the preservation of Aboriginal culture. The logical method of accomplishing this is for the court to clarify that the fiduciary duty requires the Crown to negotiate with Aboriginal peoples the institutions necessary to achieve this.

The recognition of such an obligation would be consistent with the basis of the fiduciary duty as set out in Sparrow and the existing case law interpreting s. 35 . It would be consistent with the purpose of s. 35 as enunciated by the Court. Indeed, arguably, it is necessary for the fulfillment of that purpose. It would conform to the concept of shared sovereignty as delineated by the Royal Commission, while offering the flexibility of a negotiation process for the development of sophisticated arrangements that can safeguard the future of Aboriginal languages and cultures within Canada. Finally, recognizing such an obligation would not be inconsistent with a conclusion that Aboriginal peoples in fact have an inherent right of self-government

See, e.g., "Wampum at Niagara," supra note 64 at 161-65; Worcester v. Georgia, 31 U.S. (Pet.) 515 (1832) per Marshall C.J. and, generally, R. v. Sioui, [1990] I S.C.R. 1025 [hereinafter Sioui]. Sioui, ibid. at 1053, 1055.

E.B. O'Callaghan, ed., Documents Relative to the Colonial History of the State of New York, vol. 7 (Albany: Weed, Parsons and Company, 1856) at 674.

See RCAP Report, supra note 11, vol. 2 at 166-69 and 184-213; B. Slattery, "First Nations and the Constitution: A Question of Trust" (1992) 71 Can. Bar Rev. 261; K. McNeil, "Envisaging Constitutional Aboriginal Governments" (1993) 19 Queen's L.J. 95; J. Borrows, "A Genealogy of Law: Inherent Sovereignty and First Nations Self-Government" (1992) 30 Osgoode Hall L.J. 291; M. Asch \& P. Macklem, "Aboriginal Rights and Canadian Sovereignty: An Essay on $R$. v. Sparrow" (1991) 29 Alta. L. Rev. 498; and B. Ryder, "The Demise and Rise of the Classical Paradigm in Canadian Federalism: Promoting Autonomy for the Provinces and First Nations" (1991) 36 McGill L.J. 308. 
within the Canadian Constitution, but it would ensure that self-governing institutions begin to take material form without further delay.

It might be argued that the recognition of a fiduciary duty to respect the right of Aboriginal peoples to develop and maintain the institutions necessary for the preservation of their cultures requires that the courts first accept that there is a corresponding Aboriginal right of Aboriginal peoples to exercise those essential governmental powers. As we have seen, the current requirement of proof on a case-bycase basis of particular customs, practices or traditions is not well-suited to recognition of such a broad governance right. However, there can be no doubt that the necessary mechanisms for the transmission of language, culture and the other distinctive characteristics of Aboriginal societies were universally present among Aboriginal peoples in Canada at the time of European settlement. By definition, such mechanisms were defining features of their societies, serving to preserve their distinctiveness. Accordingly, a cogent case can be made that a general constitutional right to protect the core characteristics of Aboriginal societies already exists.

Recognizing such a governance right on a universal basis across Canada would require the courts to move beyond the approach taken in s. 35 harvesting cases, but the Supreme Court in Delgamuukw has already shown a willingness to adapt the test for proof of an Aboriginal right to the nature of the right claimed. In Delgamuukw, the Court indicated that the differences in the test for Aboriginal title (a species of Aboriginal right) from the Van der Peet test ${ }^{97}$ are based on the purpose of s. 35. The requirement of a different test arises in Aboriginal title claims because, according to Lamer C.J.C., "it is clear ... that s. 35 must ... affirm both aspects of that prior presence [of Aboriginal peoples] - first, the occupation of the land, and second, the prior social organization and distinctive cultures of Aboriginal peoples on that land." 98 It is submitted that just as the nature of land occupation required a different formulation of the Aboriginal rights test, so too, for the reasons stated earlier, does the core ability of Aboriginal cultures to sustain themselves as "social organizations" and distinctive cultures. That core ability was a universal feature of Aboriginal societies. The existence of that core ability at contact should not require separate proof for each Aboriginal society that exists in Canada today.

Recognition of an independent s. 35 right to maintain the institutions necessary to preserve Aboriginal cultures is not, however, a prerequisite for judicial acknowledgement of the fiduciary duty described above. It is true that Sparrow was decided in the context of an Aboriginal rights claim. In addition, while the court in Sparrow declared that Guerin sets out the guiding principle for the interpretation of s. 35 and that the government's relationship with Aboriginal peoples is "trust-like," it went on to state that "Aboriginal rights must be defined in light of this historic relationship." ${ }^{\prime 99}$ Finally, as we have seen, the result in Sparrow was to import the feature of the group in question, and the relevant date is assertion of sovereignty, not contact. Sec Delgamuukw, supra note 4 at para. 142.

4) Sparrow, supra note 9 at 1108 [emphasis added] 
fiduciary obligation as one of the factors to be considered in the justification test for governmental infringements of s. 35 rights. However, the judgment of the Court in Sparrow clearly recognized that the fiduciary relationship is a general one, arising from the historical relationship of the parties. Furthermore, neither the judgment in Guerin defining this particular fiduciary relationship, nor the current law on fiduciary relationships in general, limit a fiduciary's obligations to defending the beneficiary's legal rights.

In finding that a fiduciary obligation arose in relation to the land surrender under consideration in Guerin, Dickson J. did so in the absence of a finding that the claimant Indian band had a continuing property right in the lands it had surrendered. Rather, it was the parties' historic relationship and the legislative scheme in relation to Aboriginal lands that required the Crown to protect the "interests" of the band. ${ }^{100}$ Subsequent decisions of the Supreme Court outside the Aboriginal context have confirmed that the determination that a fiduciary duty exists does not depend on a finding that the beneficiary of the duty had a pre-existing legal right that the putative fiduciary was bound to protect. It is sufficient that the beneficiary had a legal or practical interest that the other party should have defended. ${ }^{101}$

The indicia generally relied upon in recent Supreme Court decisions outside the Aboriginal context in determining whether a fiduciary duty exists were first set out by Wilson J. in dissent in Frame v. Smith. ${ }^{102}$ In that case Wilson J. stated,

Relationships in which a fiduciary obligation have been imposed seem to possess three general characteristics:

(1) The fiduciary has scope for the exercise of some discretion or power;

See Guerin, supra note 67 at 383-84.

See Mclnerney v. MacDonald, [1992] 2 S.C.R. 138. In concluding that a physician has a fiduciary duty that generally requires the release of medical records to a patient, La Forest J. stated, at para. 25 , "I find it unnecessary to reify the patient's interest in his or her medical records and, in particular, I am not inclined to go so far as to say that a doctor is merely a 'custodian' of medical information. The fiduciary duty I have described is sufficient to protect the interest of the patient." See also Hodgkinson v. Simms, [1994] 3 S.C.R. 377, where a financial advisor who did not disclose a financial interest in investments purchased for a client was held liable in the circumstances for breach of fiduciary duty. In Norberg v. Wynnrib, [1992] 2 S.C.R. 226, McLachlin J. stated, at 277, "as Wilson J. said in Frame v. Smith at p. 143. "[t]o deny relief because of the nature of the interest involved, to afford protection to material interests but not to human or personal interests would, it seems to me, be arbitrary in the extreme'. At the very least. the societal and personal interests at issue here constitute "a vital and substantial "practical" interest' (at p. 137), within the meaning of the second characteristic of a fiduciary duty set out in Frame v. Smith."

[1987] 2 S.C.R. 99 at 136 [hereinafter Frame v. Smith]. Although the Supreme Court of Canada has made it clear that there is no uniform test for the determination of a fiduciary duty, the analysis used by Wilson $\mathrm{J}$. has been frequently cited with approval. See, e.g., Hodgkinson $\mathrm{v}$. Simms, supra note 101 at 409 per La Forest J. (for the majority on this issue); and Lac Minerals v. International Corona Resources, [1989] 2 S.C.R. 574 at 599 per Sopinka J., and at 646 per La Forest J. See also M.(K.) v. M.(H.), [1992] 3 S.C.R. 6 at 63-64; and Blueberry River Indian Band v. Canada [1995] 4 S.C.R. 344 at 405 per McLachlin J. 
(2) The fiduciary can unilaterally exercise that power or discretion so as to affect the beneficiary's legal or practical interests; and

(3) The beneficiary is peculiarly vulnerable to or at the mercy of the fiduciary holding the discretion or power. $^{103}$

The precise content of any fiduciary duty depends upon the relationship of the parties and the relevant circumstances. ${ }^{104}$ Further, the existence of a fiduciary relationship between parties does not imply that every dealing between the parties is impressed with that duty. ${ }^{105}$ While the courts have been careful not to take a rigid approach in defining fiduciary duties, each of the three factors cited by Wilson J. supports the conclusion that the Crown's pre-existing fiduciary duty extends to the protection of the mechanisms necessary for preservation of Aboriginal cultures. The Crown, through its legislative powers under the Constitution, has the ability to exercise its discretion in this area. The Crown can unilaterally exercise that discretion to affect the vital interests of Aboriginal societies, and those distinctive societies are peculiarly vulnerable within Canada to the exercise of those powers. ${ }^{106}$ Furthermore, from a policy perspective, the continuance of a meaningful relationship between the parties and the ultimate reconciliation of those distinct societies within Canada necessitates the finding of such a duty within the overall fiduciary relationship already recognized in Sparrow. ${ }^{107}$

Logically, the duty to negotiate should extend not only to the federal government, but also to the provinces insofar as they exercise their jurisdiction in a way that affects Aboriginal societies' abilities to preserve their cultures. Culture is not a constitutional subject area allocated exclusively to either level of government, ${ }^{108}$ and valid provincial laws of general application regarding subjects as central to culture as language or education, for example, may affect the transmission of Aboriginal cultures

Frame v. Smith, ibid.

Hodgkinson v. Simms, supra note 101 at 413-14 per La Forest J.: "In summary, the precise legal or equitable duties the law will enforce in any given relationship are tailored to the legal and practical incidents of a particular relationship. To repeat a phrase used by Lord Scarman, ' $[t]$ here is no substitute in this branch of the law for a meticulous examination of the facts'; see National Westminster Bank plc v. Morgan, [1985] I All E.R. 821 (H.L.) at p. 831." Frame v. Smith, supra note 102 at 149. See also Hodgkinson v. Simms, ibid. at 412.

The Supreme Court has recognized that the lives of Aboriginal people in Canada are particularly "susceptible to government interference." Furthermore, according to the Court, the Crown has not ensured that Aboriginal peoples were "endowed with institutions and rights necessary to maintain and promote their identities against the assimilative pressures of the majority." See Reference re Quebec Secession, supra note 22 at para. 74.

For the importance of social and policy considerations in the determination of a fiduciary duty, see McInerney, supra note 99 at 152 per La Forest J. for the Court: "As I see it, it is important that the patient have access to the records for the very purposes for which it is sought to withhold the documents, namely, to ensure the proper functioning of the doctor-patient relationship and to protect the well-being of the patient." See also Hodgkinson v. Simms, supra note 101 at 408-409 per La Forest J. for the majority.

See, e.g. Kitkatla Band v. British Columbia, [2002] 2 C.N.L.R. 143 at para. 51 [hereinafter Kitkatla]. 
just as surely as federal legislation. ${ }^{109}$ Supreme Court decisions with respect to the fiduciary duty of the "Crown" do not limit the application of the duty to the federal government. ${ }^{110}$ The consideration of whether the Crown has fulfilled its fiduciary duty under the Sparrow justification test clearly applies to provincial as well as federal legislation that affects Aboriginal interests."1' The Court's explanation of the justification test clearly contemplates an active role by the provinces in seeking to accommodate Aboriginal interests, and not merely a consideration of those interests $e x$ post facto when it comes to defending provincial legislation in court. ${ }^{112}$ Finally, the analysis presented here in relation to the vulnerability of Aboriginal cultures to the exercise of Crown sovereignty, and the indicia of a fiduciary relationship referred to in Frame v. Smith, apply with just as much force to provincial emanations of the Crown affecting Aboriginal interests within their jurisdiction as they do to the federal government.

Although space does not permit a detailed elucidation of the possible content of a court-enforced duty to negotiate, in practical terms such a duty would add a level of

For the analysis to be followed in determining whether laws with an effect on Aboriginal culture will be intra vires the province, see Kitkatla, ibid., which upheld provincial heritage legislation that, among other things, permitted decision-making regarding the cutting of trees that had been culturally modified by Aboriginal people.

Indeed in Ontario (A.G.) v. Bear Island, [1991] 2 S.C.R. 570, the brief judgment of the Court implies that the province was bound by the fiduciary duty in that case. At para. 7, the court noted that the Crown owed a fiduciary duty to the appellant; a duty whose breach was "the subject of negotiations between the parties." The province was the only Crown party involved in such negotiations at the time. The B.C. Court of Appeal has recently concluded unequivocally that the Crown's fiduciary duty extends to the provinces: Taku River Tlingit First Nation v. Ringstad (2002), 98 B.C.L.R. (3d) 16 (C.A.) [hereinafter Taku River]; and Haida Nation v. British Columbia (Minister of Forests) (2002), 99 B.C.L.R. (3d) 209 (C.A.) [hereinafter Haida Nation]. For further analysis of the application of the fiduciary duty to the provinces, see B. Slattery, supra note 95. and L. Rotman, Parallel Paths: Fiduciary Doctrine and the Crown-Native Relationship in Canada (Toronto: University of Toronto Press, 1996) at 221-43.

III R. v. Cote, supra note 66. See also Delgamuukw, supra note 4 at paras. 160-69 per Lamer C.J.C. The language used by Lamer C.J.C. strongly suggests an active role by the province in accommodating Aboriginal interests where Aboriginal title will be infringed. Speaking of the fiduciary duty, he states, at para. 167, "this might entail, for example, that governments accommodate the participation of Aboriginal peoples in the development of the resources of British Columbia, that the conferral of fee simples for agriculture, and of leases and licences for forestry and mining reflect the prior occupation of Aboriginal title lands, that economic barriers to Aboriginal uses of their lands (e.g. licensing fees) be somewhat reduced." Later, at para. 168. Lamer C.J.C. makes clear that the fiduciary analysis here is based on the principles set out in Guerin: "Whether the Aboriginal group has been consulted is relevant to determining whether the infringement of Aboriginal title is justified, in the same way that the Crown's failure to consult an Aboriginal group with respect to the terms by which reserve land is leased may breach its fiduciary duty at common law: Guerin."

112 In addition to the comments referred to ibid, see, e.g. Lamer C.J.C.'s discussion of the justification test at para. 168 of Delgamuukw as it applies to infringements of Aboriginal title. After noting the relevance of Crown consultation with the Aboriginal group affected, he states. "Some cases may even require the full consent of an Aboriginal nation, particularly when provinces enact hunting and fishing regulations in relation to Aboriginal lands." It is submitted that Lamer C.J.C.'s language makes no sense if the province in such cases is not under a fiduciary duty to seek Aboriginal consent before it finalizes its legislation. This analysis has recently been adopted by the B.C. Court of Appeal in Taku River and Haida Nation, supra note 110. 
accountability to Crown negotiators. The effect would be to mitigate the imbalance of bargaining power that typically afflicts the Aboriginal party to the negotiations. Both levels of the Crown would be required to participate to the extent that their jurisdictions would be affected by the discussions. This would avoid the impasses that frequently occur when a necessary party is not at the table. In addition, at minimum a duty to negotiate in good faith would require the Crown to ensure that it consistently provides its negotiators with appropriate mandates to permit progress toward the protection of Aboriginal cultures and the ability to table concrete options for discussion at the table within reasonable timeframes.

To date, the Supreme Court has not had to confront directly the implications of the Crown's fiduciary duty outside the context of interests in reserve lands and the justification test for legislation infringing s. 35 rights. ${ }^{113}$ Lower courts, however, are increasingly being called upon to address those implications. Two recent appellate judgments in particular merit discussion here. Both deal with the ambit of the fiduciary duty in the context of Aboriginal rights claims. In the first, Haida Nation v. British Columbia ${ }^{114}$ the B.C. Court of Appeal held that the provincial Crown's fiduciary duty requires it to address Aboriginal interests prior to a court determination on an Aboriginal title claim. In the second, Perry v. Ontario, ${ }^{115}$ the Ontario Court of Appeal commented unfavourably on the possibility of there being a constitutional duty on the Crown to negotiate Aboriginal rights. I will deal with each in turn.

In Haida Nation, the British Columbia government had reissued a tree-farming license for old-growth and second-growth timber on the Queen Charlotte Islands, an area which the Haida people had occupied since before the British arrived in the area. Affidavit evidence indicated that the government had never consulted the Haida about the reissuance of the license or about long-term forestry planning in the area of the

113 After this article was accepted for publication, the Supreme Court of Canada issued its judgment in Wewaykum Indian Band v. Canada, [2002] S.C.J. No. 79, online: QL (SCJ). The Court acknowledged, at para. 79, that the Crown's fiduciary duty is not limited to protecting s. 35 rights or existing reserve interests. However, the judgment notes that the courts have faced a "flood" of fiduciary duty claims by Indian bands, and urged caution in dealing with claims to extend the Crown's liability for breach of fiduciary duty, particularly where the Crown is exercising a public law function. In Wewaykum, two Indian bands each claimed the other's reserve land and each based its claim on an alleged breach of fiduciary duty by the Crown. After reviewing what it described, at para. 105, as the "various technical arguments" made by the claimants, the Court concluded that neither band had a beneficial interest in the other's reserve and that the Crown had fulfilled its fiduciary duty to both bands. In describing the scope of the Crown's duty, Binnie J. expressly rejected the suggestion that the fiduciary duty extends to all aspects of the Crown-Indian band relationship. Although the Court ultimately found that a fiduciary duty did govern the Crown's exercise of public law functions in the case before it, Binnie J. affirmed, at para. 83, that in dealing with fiduciary claims it is necessary "to focus on the particular obligation or interest that is the subject matter of the particular dispute and whether or not the Crown had assumed discretionary control in relation thereto sufficient to ground a fiduciary obligation."

While space does not permit further discussion of the Court's dicta in Wewaykum, it is submitted that the judgment is not inconsistent with the general framework of analysis presented in this article.

III Supra note 110.

IIs (1997), 33 O.R. (3d) 705 (C.A.), leave to appeal to S.C.C. refused [1997] S.C.C. No. 2249, online:

QL (SCC) [hereinafter Perry]. 
license. A Haida claim for recognition of Aboriginal title and for Aboriginal rights in connection with the forest had not yet been adjudicated. The Haida sought a declaration that the license was invalid on the basis that their claim was an "encumbrance" on the land under the B.C. Forest $\mathrm{Act}$, and that the province had violated its fiduciary duty in failing to consult them adequately regarding the license. The province argued that no fiduciary duty arose, and no encumbrance could exist, prior to a court ruling confirming that the Haida had s. 35 rights. A unanimous bench of the B.C. Court of Appeal ruled that, although no "encumbrance" could arise before the claim was established, the Crown was nevertheless bound by its fiduciary duty to consult with the Haida and to seek to accommodate their economic and cultural interests. ${ }^{116}$

Several aspects of the Court's judgment are relevant to the analysis here. First, the Court found that the Crown's fiduciary duty is a "free standing enforceable legal and equitable duty," not one that arises only in the context of the justification test applied to Crown legislation that infringes Aboriginal rights. ${ }^{117}$ In the words of Lambert J.A. for the court, "The duty to consult and seek an accommodation does not arise simply from a Sparrow analysis of s. 35. It stands on the broader fiduciary footing of the Crown's relationship with the Indian peoples who are under its protection." 118 Second, that duty, because it arises from the general relationship of the Crown with Aboriginal peoples, binds the Crown in both of its sovereignties, federal and provincial. ${ }^{119} \mathrm{Third}$, the Court expressly took into account the pragmatic concern that awaiting final judicial determinations of s. 35 rights before requiring the Crown to act on its fiduciary duty risks leaving Aboriginal groups with few interests left to protect. ${ }^{120}$

Finally, the Court in Haida Nation rejected the Crown's argument that the Supreme Court's s. 35 jurisprudence necessitates awaiting final adjudications on s. 35 rights before giving effect to the fiduciary duty. ${ }^{121}$ The Court reviewed the judgments in Sparrow and Delgamuukw and particularly their emphasis on consultation and accommodation of Aboriginal interests in the analysis of the circumstances in which

116 Haida Nation, supra note 110 at para. 48.

$117 \quad$ lbid. at para. 55 .

118 lbid

I19 Ibid. at para. 36. The judgment appears to take for granted the application of the duty to the province.

120 The court quotes with approval, at para. 13, the majority judgment of the Court of Appeal in MacMillan Bloedel v. Mullin (1985), 61 B.C.L.R. 145 at 151, 156: "The proposal is to clear-cut the area. Almost nothing will be left. I cannot think of any native right that could be exercised on lands that have recently been logged ... The Indians wish to retain their culture on Meares Island as well as in urban museums."

121 In this the court followed with approval the ruling in Taku River, supra note 110 where it was held, albeit in different circumstances, that a fiduciary duty to consult bound the province to consult a First Nation prior to adjudication of its s. 35 claim. However, this should be contrasted with $R$. v. TransCanada Pipelines (2000), 186 D.L.R. (4th) 403 where the Ontario Court of Appeal declined to conclude that the Crown's fiduciary duty required it to consult with First Nations who claimed they had s. 35 rights that might be affected by a municipal reorganization. In TransCanada Pipelines, however, the court noted, at paras. $121-22$, that the evidence of Aboriginal claims or how they would be affected by the proposed reorganization was inadequate, leaving it "speculative" whether any s. 35 rights would be adversely affected. 
legislation infringing a s. 35 right can be justified. ${ }^{122}$ The Court concluded that that emphasis would be meaningless if the fiduciary duty did not arise until the Crown had already infringed the First Nation's rights. ${ }^{123}$ Having found that the Haida had shown a "good prima facie case" that they had Aboriginal title and Aboriginal rights in the area covered by the timber license, ${ }^{124}$ and that the Crown had been aware of the Haida's claims, the Court issued a declaration that the province's failure to consult had placed it in breach of its fiduciary duty to the Haida people. ${ }^{125}$

The decision in Haida Nation arose in the factual context of an asserted s. 35 rights claim. Still, it supports the argument that the Crown's fiduciary duty may require it to protect Aboriginal interests outside the footing of established s. 35 rights. Indeed, its impact is arguably broader than a ruling that the Crown's duty requires it to provide protection for the mechanisms that transmit Aboriginal culture. Protection of those mechanisms through the fiduciary duty would have limited impact on non-members of the Aboriginal group. The Haida decision on its face affected third parties, ${ }^{126}$ and its reasoning limits the options available to the Crown in dealing with lands and resources subject to a reasonable claim by an Aboriginal group.

The Court in Haida Nation did not declare whether the fiduciary duty may give rise to an enforceable Crown duty to negotiate with a First Nation, an issue the court stated it was happy to leave for another day. ${ }^{127}$ Earlier, in Perry, the Ontario Court of Appeal did directly confront the issue, however, concluding that neither $\mathbf{5 .} 35$ nor the Crown's fiduciary duty gives rise to a legal obligation to negotiate Aboriginal rights. The fiduciary duty, said the Court, is a "shield and not a sword" which should not be interpreted to give rise to an affirmative duty to negotiate. ${ }^{128}$ Definitions of Aboriginality were still uncertain and the scope of Aboriginal rights unknowable. Accordingly, the court concluded, "There is simply no utility in expecting that such sensitive and difficult issues should or even can be resolved by mandated settlement." 129

Before analyzing these conclusions, it is important to review their context. In Perry, the trial judge had ordered that Ontario amend its Aboriginal hunting enforcement policy to include non-status Indians. Ontario subsequently rescinded its policy, replaced it with new guidelines and advised that it was withdrawing all charges against Perry, the original claimant. The trial judge then ordered Ontario to reinstate its original policy in the form he had ordered it amended, and to enter negotiations, to be supervised by him, with all Aboriginal groups in Ontario, including the non-status group of Algonquin

Haida Nation, supra note 110 at paras. 35-40.

Ibid. at paras. 42-44. Compare the analysis at supra note 110 .

Ibid. at para. 50.

The Court did not declare the timber license void, holding, at para. 58, that this point had not been sufficiently argued and could be better decided after a ruling on the extent of any infringement of the Haida's rights.

The Court found, at para. 52, that the current holder of the timber license was bound by the same duty as the Crown to consult with the Haida and to seek to accommodate their interests.

Ibid. at para. 23.

Perry, supra note 115 at 733.

lbid. at 734. 
Indians of which Perry was a member. Along the way, the trial judge made a number of procedural decisions against Ontario that the Court of Appeal described as "heavyhanded" and insensitive. The Court of Appeal ruled that Ontario had been denied procedural fairness. This alone, said the Court, required that the appeal be allowed. ${ }^{130}$ The Court also found that the Constitution did not prevent Ontario from repealing what amounted to ministerial guidelines. Even if Ontario's original guidelines had been unconstitutional, the proper remedy should have been a declaration of invalidity, not an order revising their terms so as to "obliterate" their objective. Further, by the time of its final order, when the charges had been withdrawn and new provincial guidelines had been established, the issues before the trial judge were moot and any challenge should have been brought against the new game and fish regime. ${ }^{131}$ Finally, the Court found that the remedy of mandatory negotiations was an inappropriate one, for the reasons cited above.

Several aspects of the Perry decision are noteworthy. First, as noted above and as the Court itself indicates, ${ }^{132}$ its conclusions regarding the remedy of mandated negotiation were not necessary for the disposition of the appeal. The Court had already found the trial judge's procedural decisions to be fatally flawed and the issues themselves moot by the time of his order. Second, in contrast to Haida Nation, the court in Perry found that the interests of the Aboriginal claimants (the existence of their asserted rights) had not been established on the record, a record the Court found to be "totally unsatisfactory." 133 Third, unlike the judgment in Haida Nation, Perry was decided without the benefit of the Supreme Court's general analysis in Delgamuukw, or the specific exhortation by Lamer C.J.C. in that case, that the Crown is under a "moral, if not a legal duty to enter into and conduct negotiations in good faith" with claimants of Aboriginal rights. ${ }^{134}$ Finally, the Court noted that, at the time of the trial judge's own order of mandated negotiations, Ontario had already been engaged for several years in a different process of tripartite negotiations involving Algonquin Aboriginal rights. ${ }^{135}$

While the Court of Appeal's comments in Perry about the appropriateness of mandated negotiations will have to be addressed in any judicial determination of whether the Crown owes an active duty to negotiate Aboriginal rights, the judicial and factual background in Perry was highly unusual. Recall that the question addressed in Perry was the appropriateness of mandating court-supervised settlement of disparate claims as a remedy for the alleged violation of constitutional rights. And the Court in Perry (unlike the court in Haida Nation) was clearly unconvinced that any such rights had been violated by the Crown. In the end, the Court in Perry was concerned with a very different question than the one posed here: whether the Crown's sovereign power incorporates a corresponding duty to protect the core ability of Aboriginal societies to preserve and transmit their cultures. That is a question that was neither raised nor 
addressed in Perry or Haida Nation, and remains to be addressed on its own merits. It is a question that goes to the heart of the fiduciary relationship and the effectiveness of the fiduciary principles described above. The answer the courts give will play a large part in determining whether the shield of the fiduciary relationship is strong enough to safeguard the continued existence of the distinctive societies it is intended to protect.

\section{CONCLUSION}

The precise content of the Crown's fiduciary duty to Aboriginal peoples remains uncertain. This article has argued that the fiduciary duty includes an obligation to negotiate in good faith the mechanisms necessary to preserve Aboriginal cultures. Such a conclusion would be faithful to the principles set out by the Supreme Court in interpreting s. 35 of the Constitution Act, 1982. It would be a major step toward giving content to the sharing of sovereignty referred to by Binnie J. in Mitchell. Recognizing such an obligation would also reflect the historical evolution in the Crown's awareness of the value of distinctive Aboriginal cultures to Aboriginal peoples and to Canada as a whole - an awareness that was absent in western societies in general until recently. ${ }^{136}$

The duty of protection described here derives from the historic relationship between the Crown and Aboriginal peoples and the current vulnerability of Aboriginal cultures to destruction. Acknowledging that this duty flows from basic fiduciary principles would mean that the legal protection of Aboriginal cultures would not be limited to a patchwork of case-by-case analyses of narrowly defined ancestral practices. The recognition of such a duty would of necessity be framed at a high level of generality, ${ }^{137}$ but a purpose-focused constitutional obligation to negotiate the mechanisms necessary for the protection and flourishing of diverse Aboriginal cultures offers far greater hope of meaningfully contributing to the survival of those cultures than does the current approach to $\mathrm{s} .35$ unmodified.

136. It would be open to the Court to find that this duty crystallized in 1982 with the Constitution's recognition and affirmation of Aboriginal and treaty rights. Alternatively, the courts could determine that the duty is a prospective one, negating claims for compensation for past failures to protect the essential mechanisms of Aboriginal cultures. 